\title{
Impacted foreign bodies in orbital region: review of nine cases
}

\author{
Corpo estranho impactado na região orbital: revisão de nove casos
}

Thiago de Santana Santos ${ }^{1}$, Auremir Rocha Meloํ․ Hécio Henrique Araújo de Moraes ${ }^{1}$, Paulo Almeida Júnior², Edwaldo Dourado ${ }^{1}$

\begin{abstract}
Orbital injuries with a foreign body may result in severe structural and functional damage to the eye or orbital contents. Management and prognosis depend on the composition and location of the foreign body and whether there is secondary infection. Metallic objects and glass are the most frequently encountered and well-tolerated, whereas organic foreign bodies can elicit an inflammatory reaction and lead to serious complications. Despite the modern imaging methods, it is often difficult to identify and locate organic intraorbital foreign bodies. This paper presents a review of nine cases of impacted foreign bodies in the orbital region and discusses the diagnosis and treatment of this kind of injury. The following data were collected:age, gender, etiology of injury, occurrence of fracture, anatomical location of fracture, type of object, signs and symptoms, type of imaging exam used, approach, transoperative complication and occurrence of death. Foreign body injuries in the orbital region can be treated with a combination of clinical suspicion, basic knowledge and diagnostic tests and depend on the skill and experience of the surgeon, thereby decreasing the surgical risk of iatrogenic injury in relation to the inherent risk of retaining an organic intraorbital foreign body.
\end{abstract}

Keywords: Orbital fractures; Eye foreign bodies; Maxillofacial injuries/surgery; Case reports; Human; Male; Adult

\section{RESUMO}

A apresentação clínica do corpo estranho orbitário é variável. Traumatismos orbitários com um corpo estranho podem provocar danos estruturais e funcionais graves para os olhos ou o conteúdo orbital. O tratamento e o prognóstico dependem da composição, localização e presença ou não infecção secundária. Objetos metálicos e de vidro são os mais frequentes e bem tolerados, enquanto corpos estranhos orgânicos podem provocar reação inflamatória que leva a sérias complicações. É frequentemente difícil identificar e localizar corpos estranhos orgânicos intraorbitais, apesar de modernos métodos de exames de imagens. Com vista a ilustrar e discutir o diagnóstico e tratamento deste tipo de lesão, este estudo apresenta uma revisão de nove casos de corpos estranhos impactados na região orbital. Os seguintes dados foram coletados: idade, sexo, etiologia, ocorrência de fratura, localização anatômica da fratura tipo de objeto, sinais e sintomas, tipo de exame de imagem utilizado, abordagem, complicação trans-operatória e a ocorrência de morte. Ferimentos provocados por corpos estranhos na região orbital podem ser tratados pela combinação da suspeita clínica, testes de conhecimentos básicos de diagnóstico, habilidade e experiência do cirurgião. A soma de tais fatores leva à redução do risco de iatrogenia em relação ao risco inerente de retenção intraorbitária de corpo estranho orgânico.

Descritores: Fraturas orbitárias; Corpos estranhos no olho; Traumatismos maxilofaciais/cirurgia; Relatos de casos; Humanos; Masculino; Adulto

\section{INTRODUCTION}

0 bital injuries with a foreign body may result in severe structural and functional damage to the eye or orbital contents. Amaurosis, fulminant orbital phlegmon leading to enucleation and orbital fracture with possible brain injury and meningitis have been reported following accidents with wooden intraorbital particles ${ }^{(1-4)}$. A metallic foreign body in the intraocular region may be associated to a rare condition known as ocular siderosis, which is clinically characterized by heterochromia, mydriasis, pigmentation of the structures of the anterior chamber, an increase in intraocular pressure, etc ${ }^{(5-6)}$.

The clinical presentation of an orbital foreign body is variable. Management and prognosis depend on the composition and location of the object and whether there is secondary infection. Metallic objects and glass are the most frequently encountered and well-tolerated, whereas organic foreign bodies can elicit an inflammatory reaction and lead to serious complications. Despite modern imaging methods, it is

Work carried out at Hospital da Restauração em Recife.

1 Physician, Faculdade de Odontologia de Pernambuco - FOP - Recife (PE), Brazil.

2 Physician, Universidade Tiradentes - UNIT - Aracajú (SE), Brazil.

Correspondence address: Edwaldo Dourado. Faculdade de Odontologia de Pernambuco/Universidade de Pernambuco. Av. General Newton Cavalcanti, 1.650 - Camaragibe (PE) - CEP 54753-220 - E-mail: thiago.ctbmf@yahoo.com.br

Recebido para publicação em 13.03.2010

Última versão recebida em 12.07.2010

Aprovação em 15.10.2010 often difficult to identify and locate organic intraorbital foreign bodies $^{(7)}$.

A wooden intraorbital foreign body is usually difficult to detect through conventional diagnostic methods ${ }^{(8-9)}$. When such a body is not detected during an initial ophthalmological exam, it may be retained for a long time until it is recognized through some ocular symptom or through plain x-rays, computed tomography (CT) or echography. Some authors reported two cases of suspected intraorbital wooden foreign bodies using $\mathrm{CT}$ scans, in both of which magnetic resonance imaging (MRI) clearly showed a well-delineated, low-intensity, intraorbital injury ${ }^{(8)}$.

Unlike small foreign bodies, which are generally located completely within the orbit, large impacted objects in the orbital region cause severe visual impact and require specialized care within as short a period of time as possible ${ }^{(9)}$. The approach to this kind of injury should be sequential and multidisciplinary, beginning with the trauma unit, which provides maintenance of the airways and hemodynamic stabilization, followed by neurological, ophthalmologic and vascular evaluation ${ }^{(10-11)}$.

This paper presents a review of nine cases of impacted foreign bodies in the orbital region and discusses the diagnosis and treatment of this kind of injury.

\section{METHODS}

Nine patients consecutively treated at the Oral and Maxillofacial Surgery Department of a public hospital in the city 
of Recife (Pernambuco, Brazil), presenting to the emergency unit with impacted foreign bodies in the orbital region between January, 2008 and January, 2010 were evaluated retrospectively. These patients had been submitted to the surgical removal of foreign bodies with different degrees of severity. Following general anesthesia by orotracheal or nasotracheal intubation, the foreign body was removed back along its path of insertion, with care being taken with hemostasis. The patients received tetanus prophylaxis and antibiotic therapy. The following data were collected: age, gender, etiology of injury, occurrence of fracture, anatomical location of fracture, type of object, signs and symptoms, type of imaging exam used, approach and transoperative complications.

\section{RESULTS}

Table 1 displays the collected data from the nine patients. Mean age was 31.4 years. All patients were male. The main etiological factor was physical aggression in three cases (33.3\%). Accidents involving firearms and falls accounted for two cases (22.2\%) each. There was one case of a motorcycle accident and one case of a work-related accident involving a saw.

CT was used in all cases for the exact localization of the foreign body, determination of possible deep tissue damage and surgical planning. In three cases, $x$-rays of the head and face were initially taken, but visualization using CT was needed for a better assessment of the extension of the object and its location, even with the foreign body exposed externally.

The foreign body caused fractures in the orbital and adjacent regions in five patients. Pain was reported by all patients, with the exception of one case in which there was severe neurological impairment (Case 5). Amaurosis was detected in four cases (44.4\%) and ophthalmoplegia was detected in two cases $(22.2 \%)$. A wooden rod was the most common foreign body (5 cases). The only transoperative complication was associated with one case with brain injury and death of the patient.

\section{DISCUSSION}

Most eye injuries involving the penetration of a foreign body exhibit minimal surface damage, which may often be undervalued by the physician during the initial evaluation. Orbital fat tends to conceal the trajectory, making it difficult to identify a point of entry. Thus, suspicion is crucial to defining the diagnosis ${ }^{(12-13)}$.

The possibility of a foreign body should be considered following a history of trauma with persistent signs of inflammation, limited eye movement, difficulty healing or deterioration of the clinical condition ${ }^{(14-16)}$. The cause of limited eye movement should be assessed with care, as it may have been caused by the presence of a foreign body, trauma to the oculumotor, trochlear and abducent nerves or muscle imprisonment on fractures in the orbital walls.

A prospective study carried out over a two-year period at the Getúlio Vargas Hospital in Recife (PE, Brazil) involving 713 patients with ocular trauma due to foreign bodies revealed that $96.21 \%$ were male, with a predominance of the third decade of life; the majority of the cases occurred during work activities (61.29\%) and metal was the most common type of foreign body type found $(75.17 \%)^{(17)}$. In the present study, all cases involved males and the mean age was 30.25 years, with four cases in the third decade of life. Only one case (Case 9) involved work-related activities. An organic foreign body (wood) was the most common type of object, occurring in five cases.

The clinical examination of patients with an impacted object in the face should be carried out in a systematic fashion ${ }^{(11)}$. Active wound bleeding, increasing hematoma, a low level of hemoglobin and signs of hypovolemic shock upon admission are indications of an associated vascular injury ${ }^{(18)}$. Ocular acuity and mobility should be investigated, as penetrating wounds in the orbit are frequently associated with severe ocular trauma ${ }^{(10,19)}$. In this review of cases, five patients had fractures. However, the presence fracture proved not to be a premise for establishing that the wound would induce amaurosis, as three of the four cases with amaurosis had no fractures. Despite not having a direct injury to the optic nerve, two victims of

Table 1. Characterization of patients

\begin{tabular}{|c|c|c|c|c|c|c|c|c|c|c|c|}
\hline Case & Age & Gender & Etiology & Fracture & Localization & Object type & $\begin{array}{l}\text { Signal and } \\
\text { symptoms }\end{array}$ & $\begin{array}{l}\text { Image } \\
\text { exam }\end{array}$ & Approach & $\begin{array}{l}\text { Intra-operative } \\
\text { complication }\end{array}$ & Death \\
\hline 1 & 15 & $M$ & $\begin{array}{l}\text { Accident } \\
\text { with rifle }\end{array}$ & No & Right orbit & $\begin{array}{l}\text { Fragment } \\
\text { from rifle }\end{array}$ & $\begin{array}{c}\text { Pain, } \\
\text { amaurosis }\end{array}$ & $C T$ & $\begin{array}{l}\text { Same path } \\
\text { as insertion }\end{array}$ & No & No \\
\hline 2 & 12 & M & Fall & Yes & Right orbital floor & Woodrod & $\begin{array}{c}\text { Pain, } \\
\text { ophtalmoplegia }\end{array}$ & $\mathrm{CT}$ & $\begin{array}{l}\text { Same path } \\
\text { as insertion }\end{array}$ & No & No \\
\hline 3 & 37 & M & $\begin{array}{c}\text { Physical } \\
\text { aggression }\end{array}$ & No & Right orbit & Woodrod & $\begin{array}{l}\text { Pain, } \\
\text { amaurosis }\end{array}$ & $C T$ & $\begin{array}{l}\text { Same path } \\
\text { as insertion }\end{array}$ & No & No \\
\hline 4 & 37 & M & $\begin{array}{c}\text { Physical } \\
\text { aggression }\end{array}$ & No & Right orbit & Woodrod & $\begin{array}{c}\text { Pain, } \\
\text { ophtalmoplegia }\end{array}$ & CT & $\begin{array}{l}\text { Same path as } \\
\text { insertion }\end{array}$ & No & No \\
\hline 5 & 35 & M & $\begin{array}{l}\text { Motorcycle } \\
\text { accident }\end{array}$ & Yes & $\begin{array}{l}\text { Left orbital apex } \\
\text { and sphenoid }\end{array}$ & $\begin{array}{l}\text { Motorcycle } \\
\text { handlebars }\end{array}$ & Brain injury & $\begin{array}{c}\text { PA, lateral } \\
\text { x-ray skull, CT }\end{array}$ & $\begin{array}{c}\text { Same path as } \\
\text { insertion + coronal }\end{array}$ & Bleeding & Yes \\
\hline 6 & 31 & M & $\begin{array}{c}\text { Physical } \\
\text { aggression }\end{array}$ & Yes & Right orbital floor & Woodrod & Pain, amaurosis & $\begin{array}{c}\text { PA, lateral } \\
\text { x-ray skull, } C T\end{array}$ & $\begin{array}{l}\text { Same path } \\
\text { as insertion }\end{array}$ & No & No \\
\hline 7 & 51 & M & Fall & Yes & Right orbital floor & Woodrod & Pain & CT & $\begin{array}{l}\text { Same path } \\
\text { as insertion } \\
+ \text { infraorbital }\end{array}$ & No & No \\
\hline 8 & 24 & M & $\begin{array}{l}\text { Accident } \\
\text { with rifle }\end{array}$ & No & Left orbit & $\begin{array}{l}\text { Fragment } \\
\text { from rifle }\end{array}$ & $\begin{array}{l}\text { Pain, } \\
\text { amaurosis }\end{array}$ & CT & $\begin{array}{l}\text { Same path } \\
\text { as insertion }\end{array}$ & No & No \\
\hline 9 & 41 & M & $\begin{array}{c}\text { Accident } \\
\text { with tile saw }\end{array}$ & Yes & $\begin{array}{l}\text { Left orbital roof } \\
\text { Left ethmoid and } \\
\text { sphenoid }\end{array}$ & Tile saw & $\begin{array}{l}\text { Pain, brain } \\
\text { injury }\end{array}$ & $\begin{array}{l}\text { PA, lateral x-ray } \\
\text { skull, CT }\end{array}$ & $\begin{array}{c}\text { Same path as } \\
\text { insertion } \\
\text { + coronal }\end{array}$ & No & No \\
\hline
\end{tabular}

$\mathrm{CT}$ = computed tomography, $\mathrm{PA}=$ posterior-anterior 


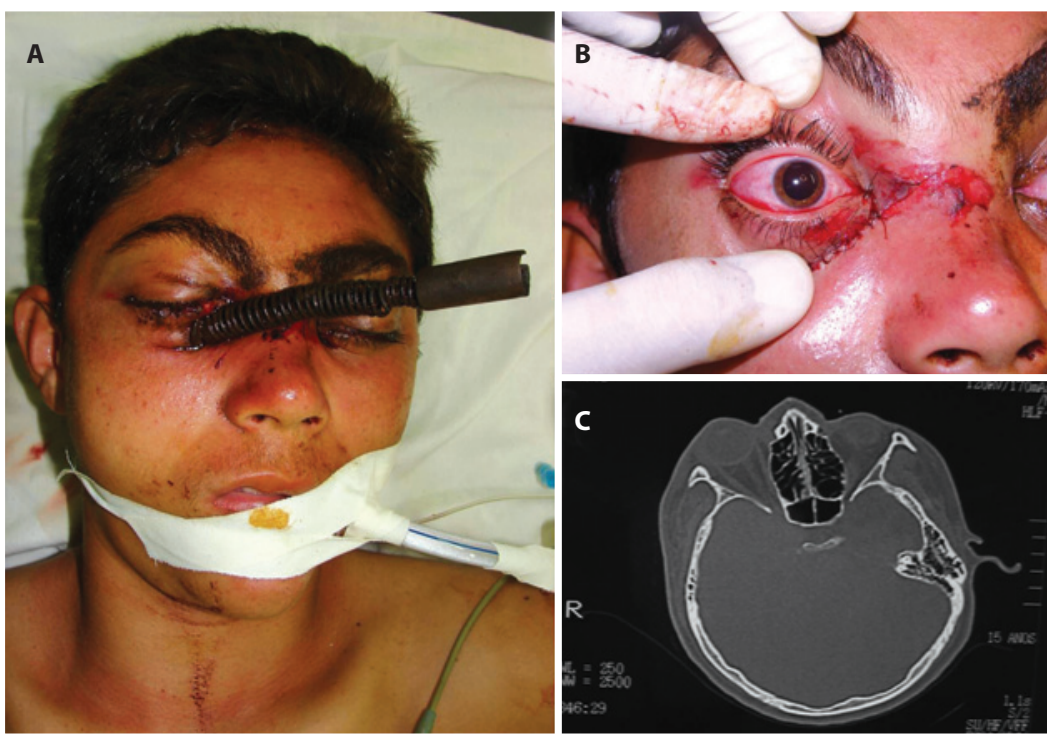

Figure 1. A) Impacted foreign body in right orbit; B) Amaurosis evident by absence of myosis with exposure to light in right eye; C) Computed tomography (axial view) showing integrity of optic nerve.

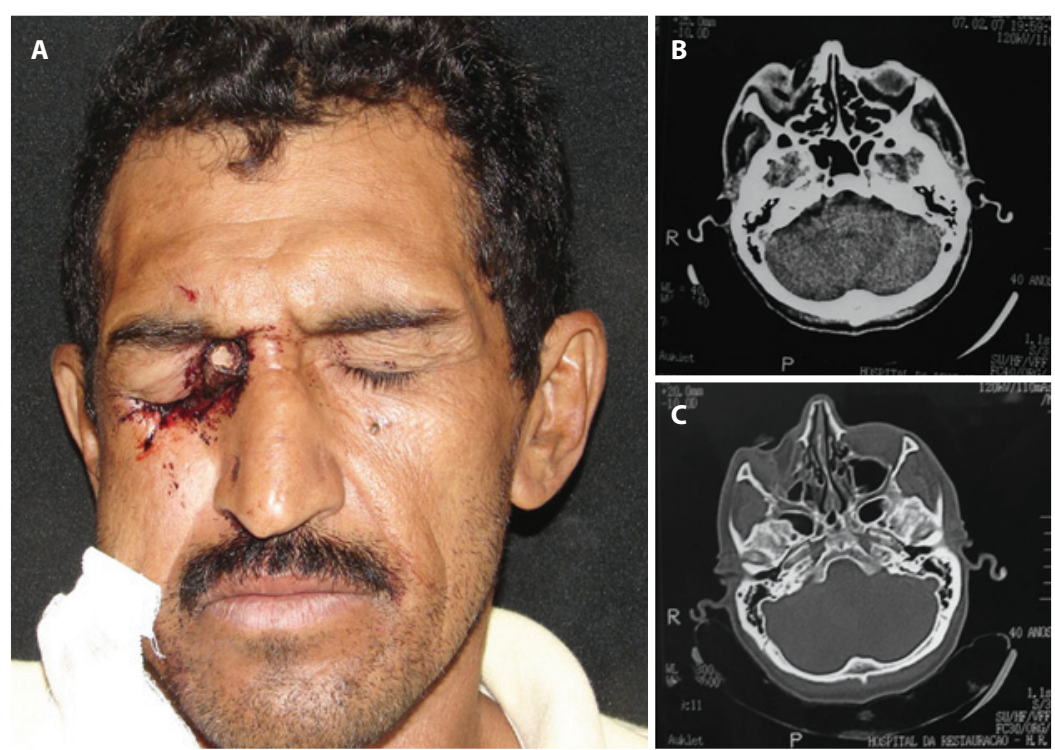

Figure 2. A) Wooden splinter in right orbit; B) Soft tissue window in computed tomography (axial view) showing space similar to air in right orbit; C) Hard tissue window in computed tomography (axial view) showing space similar to air in right orbit.

firearm accidents (Cases 1 and 8) exhibited amaurosis, likely due to the penetration of a foreign body at a high temperature. The other two patients were victims of aggression with a wooden object (Cases 3 and 6) and exhibited amaurosis due to direct trauma to the ocular globe (Figures 1A, 1B, 1C). In the only case with deep penetration of the foreign body (Case 5), the $C T$ revealed the presence of the object in the region of the apex of the orbit (optic nerve). This patient exhibited neurological impairment as well as vascular injury and subsequently died. It was therefore not possible to clinically assess the occurrence of amaurosis.

Plain radiography is usually the first additional exam to be requested due to its low cost and easy access. This imaging exam may be useful in identifying and locating intraorbital foreign bodies, with detection rates of 69 to $90 \%$ for metallic foreign bodies and 71 to $77 \%$ for glass; however, the detection rate for organic material, such as wood, is low (0 to $15 \%)^{(20-21)}$. Two x-rays (frontal and lateral) should be taken to determine the location of the foreign body and its relationship with the cranial fossa $a^{(10,22-23)}$. In more complex cases, CT is essential and is an important means of diagnosing neurological injuries. When vascular injury or the anatomical proximity to large vessels is suspected, angiography can be performed ${ }^{(18,22)}$. In cases of hemorrhage in inaccessible sites, angiography can locate the blood vessel involved and obstruct it through selective embolization. ${ }^{(24)}$ In the present case review, posterior-anterior and lateral skull $x$-rays were obtained to confirm the descending trajectory of the foreign body, however, it was not possible to identify precisely the foreign body location (cases 5, 6 and 9). So the CT was used in all cases. 


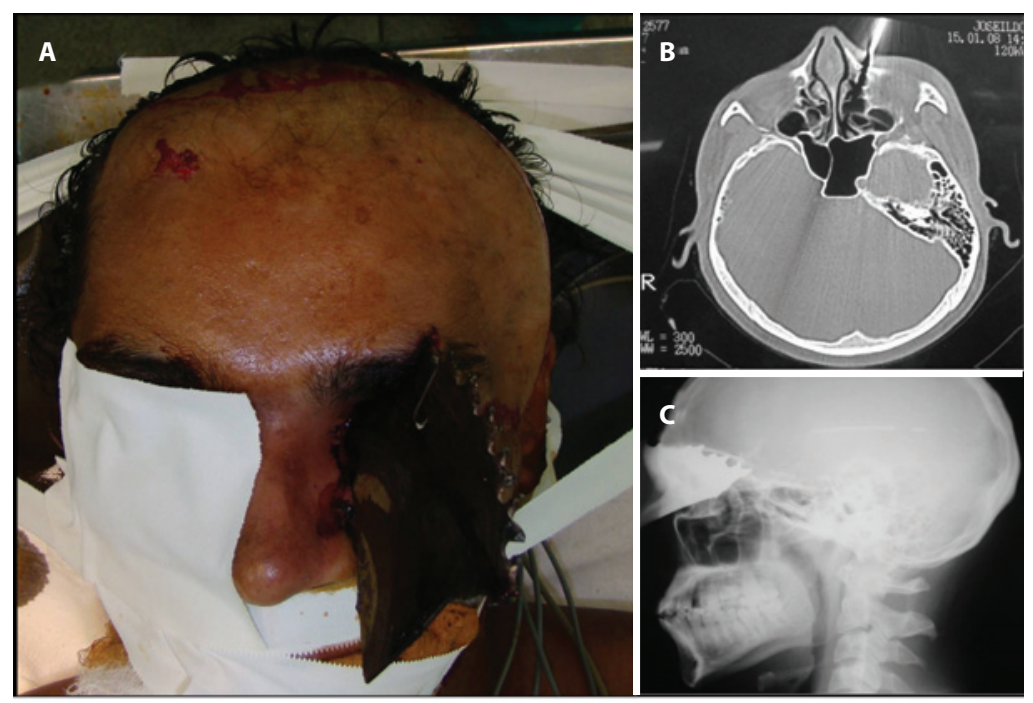

Figure 3. A) Impacted foreign body in left orbit; B) Computed tomography (axial view) showing fracture in ethmoid cells; $C$ ) Lateral $x$-ray of skull with a radiopaque object.
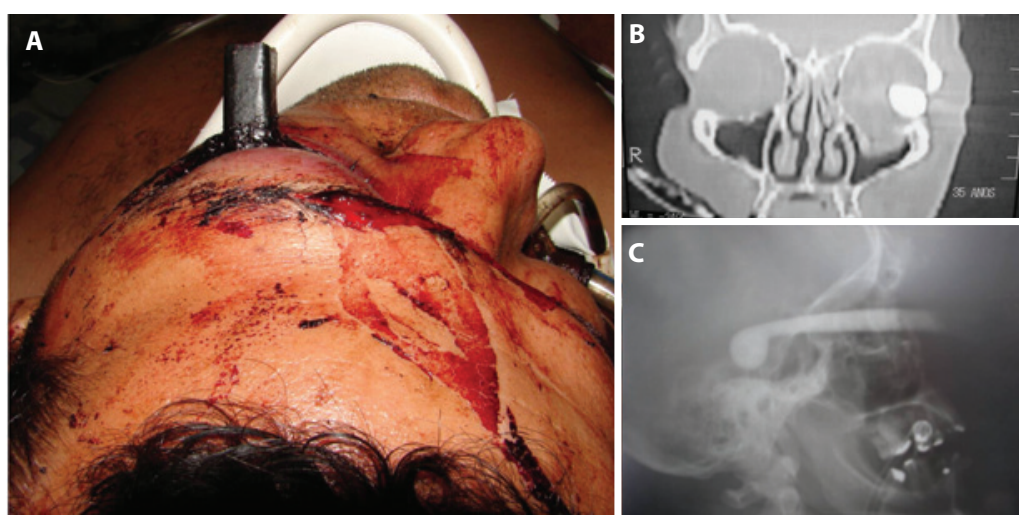

Figure 4. A) Foreign body in left orbit; B) Computed tomography (coronal view) showing object in right orbit; C) Lateral x-ray of skull showing object in sella turcica region.

$\mathrm{CT}$ is reported to be the best method for the detection of a metallic foreign body ${ }^{(21)}$. However, dry wood may present a similar $C T$ density as that of air, making its identification difficult(2). Cases 3 (Figures 2A, 2B, 2C) and 9 (Figures 3A, 3B, 3C) exemplify the differences between metallic and organic structures in imaging exams. The authors of this paper suggest the use of magnetic resonance imaging, but this method should be avoided when there is the suspicion of metallic foreign body, as the magnetic field may lead to the movement of the metallic structure. Specht et al. report a case of a boy with a history of trauma involving an organic foreign body for which surgical exploration and the CT scan were negative. CT showed a finding compatible with air, suggesting orbital emphysema. The granulation tissue surrounding the wooden foreign body could not be distinguished from the moist foreign body by means of CT scanning ${ }^{(2)}$. The percentage of water content may be different in each case ${ }^{(25)}$. In the present review, five cases involved a wooden rod, but plain radiography and $C T$ were enough to plan the treatment, as the foreign bodies were partially outside of the insertion path in all cases.

The orbit provides access to the cranial cavity, making it vulnerable to penetrating trauma, which can involve the me- ninges and central nervous system. Penetrating cranio-orbital trauma has a much higher mortality rate than other types of trauma ${ }^{(26)}$. In the present review, Case 5 involved a foreign body penetrating the orbital region, with a subsequent brain injury and bleeding complication, resulting in the death of the patient (Figures 4A, 4B, 4C)

Foreign body injuries in the orbital region can be treated with a combination of clinical suspicion, basic knowledge and diagnostic tests and depend on the skill and experience of the surgeon, thereby decreasing the surgical risk of iatrogenic injury in relation to the inherent risk of retaining an organic intraorbital foreign body.

\section{REFERENCES}

1. Agarwal PK, Kumar H, Srivastava PK. Unusual orbital foreign bodies. Indian J Ophthalmol 1993;41(3):125-7.

2. Specht CS, Varga JH, Jalali MM, Edelstein JP. Orbitocranial wooden foreign body diagnosed by magnetic resonance imaging. Dry wood can be isodense with air and orbital fat by computed tomography. Surv Ophthalmol. 1992;36(5):341-4.

3. Herman M, Vaiková Z. Intraorbital wood foreign bodies. Radiology 1993;188(3):878. Comment in: Radiology. 1994;190(2):583. Comment on: Radiology. 1992;185(2):507-8.

4. Valkova Z, Herman M. [An intraorbital foreign body with a fulminant phlegmon]. Cesk Oftalmol. 1992;48(6):406-11. Czech. 
5. Shaikh S, Blumenkranz MS. Fluorescein angiographic findings in ocular siderosis. Am J Ophthalmol. 2001;131(1):136-8.

6. Sangermani C, Mora P, Mancini C, Vecchi M, Gandolfi SA. Ultrasound biomicroscopy in two cases of ocular siderosis with secondary glaucoma. Acta Ophthalmol. 2010;88(1):e1-2.

7. Casanova FHC, Mello Filho PAA, Nakanami DM, Manso PG. Corpo estranho orgânico intraorbitário: avaliação tomográfica e conduta. Arq Bras Oftalmol 2001:64(4)·297-301.

8. Green BF, Kraft SP, Carter KD, Buncic JR, Nerad JA, Armstrong D. Intraorbital wood.

Detection by magnetic resonance imaging. Ophthalmology. 1990;97(5):608-11. Comment in: Ophthalmology. 1991;98(3):274-5. Ophthalmology. 1990;97(11):1400.

9. Yago K, Suzuki M, Sasaki S, Nakamura Y. Wooden foreign body in the orbit. Jpn 」 Clin Ophthalmol. 1990:44:439-41.

10. Harris AMP, Wood RE, Nortjé CJ, Grotepass F. Deliberately inflicted, penetrating injuries of the maxillofacial region (Jael's syndrome). Report of 4 cases. J Craniomaxillofac Surg. 1988:16(2):60-3.

11. Hudson DA. Impacted knife injuries of the face. Br J Plast Surg. 1992;45(3):222-4

12. Bullock JD, Warwar RE, Bartley GB, Waller RR, Henderson JW. Unusual orbital foreign bodies. Ophthal Plast Reconstr Surg. 1999:15(1):44-51.

13. Brock L, Tanenbaum HL. Retention of wooden foreign bodies in the orbit. Can J Ophthalmol. 1980;15(2):70-2.

14. Tuppurainen K, Mantyjarvi M, Puranen M. Wooden foreign particles in the orbit spontaneous recovery. Acta Ophthamol Scand 1997:75(1):109-11.

15. Cartwright MJ, Kurumety UR, Frueh BR. Intraorbital wood foreign body. Ophthal Plast Reconstr Surg. 1995;11(1):44-8.
6. Macrae JA Diagnosis and management of a wooden orbital foreign body: case report. Br J Ophthamol. 1979;63(12):845-51.

17. Leal FAM, Silva e Filho AP, Neiva DM, Learth JCS, Silveira DB. Trauma ocular ocupacional por corpo estranho superficial. Arq Bras Oftalmol 2003:66(1):57-60.

18. Kreutz RW, Bear SH. Selective emergency arteriography in cases of penetrating maxillofacial trauma. Oral Surg Oral Med Oral Pathol. 1985;60(1):18-22.

19. Cohen MA, Boyes-Varley G. Penetrating injuries to the maxillofacial region. J Oral Maxillofac Surg. 1986:44(3):197-202

20. Bray LC, Griffiths PG. The value of plain radiography in suspected intraocular foreign body. Eye (Lond). 1991;5(Pt 6):751-4.

21. Wilson WB, Dreisbach JN, Lattin DE, Stears JC. Magnetic resonance imaging of nonmetallic orbital foreign bodies. Am J Ophthalmol. 1988;105(6):612-7.

22. Daya NP, Liversage HL. Penetrating stab wound injuries to the face. SADJ. 2004; 59(2).55-9.

23. Shinohara $E H$, Heringer $L$, de Carvalho JP. Impacted knife injuries in the maxillofacial region: report of 2 cases. J Oral Maxillofac Surg. 2001;59(10):1221-3.

24. Subburaman N, Sivabalan K, Ramachandran M, Chandrasekhar D. Impacted knife injury of the orbit, maxilla and oropharynx. Indian J Otolaryngol Head Neck Surg [Internet]. 2005 [cited 2009 Feb 12]:57(4):347-50. Available from: http://medind. nic.in/ibd/t05/i4/ibdt05i4p347.pdf

25. Yoshii M, Enoki T, Mizukawa A, Okisaka S. Intraorbital wooden foreign body. Acta Ophthalmol Scand. 2004:82(4):492-3.

26. Nasr AM, Haik BG, Fleming JC, Al-Hussain HM, Karcioglu ZA. Penetrating orbita injury with organic foreign bodies. Ophthalmology. 1999;106(3):523-32

XVIII Curso Pan-americano da Associação Pan-americana de Oftalmologia, Sociedade Portuguesa de Oftalmologia

I Encontro de Dois Continentes
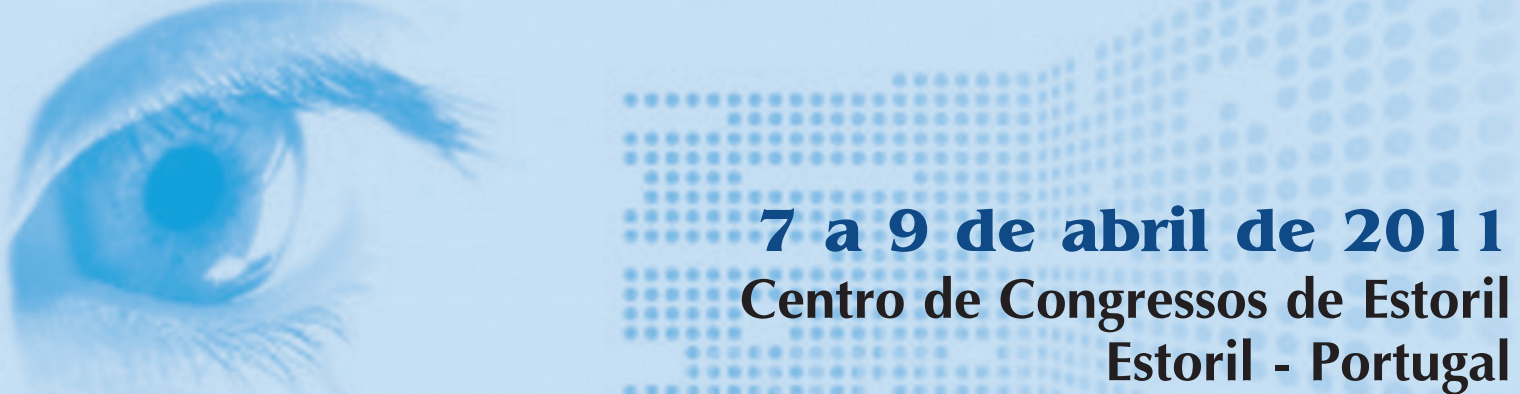

Informações:

Site: www.paaoeurope.org 